\title{
ANALISIS HASIL BELAJAR MAHASISWA JURUSAN FISIKA BERDASARKAN JALUR MASUK (SNMPTN, SBMPTN DAN MANDIRI) UNIVERSITAS NEGERI MAKASSAR
}

\section{THE ANALYSIS OF LEARNING OUTCOMES OF STUDENTS DEPARTMENT OF PHYSICS BASED ON ENTRANCE (SNMPTN, SBMPTN, AND MANDIRI) UNIVERSITAS NEGERI MAKASSAR}

\author{
${ }^{1)}$ Dewi Lestari, ${ }^{2)}$ Herman Anis, ${ }^{3)}$ Khaeruddin \\ Universitas Negeri Makassar \\ Kampus UNM Parangtambung Jln. Daeng Tata Raya, Makassar, 90224 \\ 1)e-mail : dewilestary1693@gmail.com
}

\begin{abstract}
Abstrak. Analisis Hasi Belajar Mahasiswa Jurusan Fisika Berdasarkan Jalur Masuk (SNMPTN, SBMPTN dan Mandiri) Universitas Negeri Makassar.Penelitian ini bertujuan untuk mengetahui deskripsi hasil belajar mahasiswa Jurusan Fisika berdasarkan jalur masuk SNMPTN, SBMPTN, dan Mandiri Universitas Negeri Makassar. Jenis penelitian ini adalah penelitian Deskriptif. Subyek penelitian ini mahasiswa jurusan Fisika angkatan 2017 pada semester ganjil tahun akademik 2017/2018 sebanyak 129 mahasiswa. Hasil penelitian yang diperoleh dari analisis deskriptif dari skor hasil tes sebanyak 2 kali selama semester ganjil tahun akademik 2017/2018 pada tes I skor rata-rata mahasiswa SNMPTN 5,28, SBMPTN 6,2, dan Mandiri 5,78. Pada tes II skor rata-rata mahasiswa SNMPTN 5,57, SBMPTN 6,33, dan Mandiri 5,07. Berdasarkan tes I dan II skor rata-rata mahasiswa SNMPTN 10,54, SBMPTN 12,46, dan Mandiri 10,64. Berdasarkan Analisis IPK persentase kriteria cumlaude tertinggi adalah mahasiswa SBMPTN sebesar 17,78\%, sedangkan mahasiswa SNMPTN dan Mandiri memiliki persentase sama yakni 2,38\%.
\end{abstract}

Kata kunci : Jalur SNMPTN, Jalur SBMPTN, Jalur Mandiri, Hasil Belajar

Abstract. The Analysis of Learning Outcomes of Students Department of Physics Based on Entrance (SNMPTN, SBMPTN and MANDIRI) Universitas Negeri Makassar. This research aim for knowing description learning outcomes college student Department Physics based on entrance SNMPTN, SBMPTN, and Mandiri Makassar Universitas Negeri Makassar. This research type is Descriptive research. The Subject of this research is Physics college student force 2017 in odd semester Academic year 2017/2018 as many as 129 students. Research result from descriptive analysis from score results test 2 times during odd semester academic year 2017/2018 on test I average score of SNMPTN 5,28, SBMPTN 6.2, and Mandiri 5.78. On test II student's average score of SNMPTN 5,57, SBMPTN 6.33, and Mandiri 5.07. Based on test I and II the average score of students of SNMPTN 10,54, SBMPTN 12.46, and Mandiri 10.64. Based on GPA analysis percentage criteria cumlaude highest is SBMPTN students amounted to 17,78\%, while SNMPTN students and Mandiri have percentage same i.e 2.38\%.

Keywords: SNMPTN, SBMPTN, Mandiri entrance, Learning Outcomes

\section{PENDAHULUAN}

Rekrutmen mahasiswa baru telah mengalami perubahan dan penyempurnaan dari waktu ke waktu. Perubahan tersebut dilakukan dengan tujuan meningkatkan kualitas dan keefektifan sistem pendidikan di Indonesia. Setiap perubahan seleksi penerimaan mahasiswa baru selalu banyak diperdebatkan. Topik perdebatan tersebut berkisar pada akurasi dan keadilan (equity). Kedua faktor ini merupakan tuntutan perguruan tinggi dan masyarakat yang berharap ke depan kiranya kedua faktor tersebut menjadi acuan dominan dalam penentuan model seleksi mahasiswa baru di Perguruan Tinggi Negeri (PTN). Hal ini menunjukkan bahwa sistem seleksi yang telah ada masih perlu terus diperbaiki dan disesuaikan dengan perkembangan pendidikan dan tuntutan masyarakat (Usman, 2015).

Kegiatan seleksi masuk perguruan tinggi dimaksudkan untuk memperoleh calon mahasiswa yang unggul. Kesempatan untuk 
mengikuti seleksi diberikan kepada seluruh siswa/siswi tamatan SMU/SMK, dan MA. Tes masuk mahasiswa di perguruan tinggi negeri terdiri atas tiga macam jalur seleksi, yaitu Seleksi Nasional Masuk Perguruan Tinggi Negeri (SNMPTN), Seleksi Bersama Masuk Perguruan Tinggi Negeri (SBMPTN), dan jalur Mandiri (Saputra, 2016).

Berkaitan dengan Peraturan Menteri Pendidikan Nasional Nomor 34 Tahun 2010 maka penerimaan mahasiswa baru PTN sejak Tahun 2013 dapat dikelompokkan dalam beberapa jalur yaitu: (1) Seleksi Nasional Masuk Perguruan Tinggi Negeri (SNMPTN) atau jalur undangan; (2) Seleksi Bersama Masuk Perguruan Tinggi Negeri (SBMPTN); (3) Jalur Mandiri yang pelaksanaannya diserahkan sepenuhnya ke setiap PTN. Seiring dengan dikeluarkannya Peraturan Pemerintah Republik Indonesia Nomor 66 Tahun 2010 tentang perubahan atas Peraturan Pemerintah Nomor 17 Tahun 2010 tentang Pengelolaan dan Penyelenggaraan Pendidikan dan Peraturan Menteri Pendidikan Nasional Nomor 34 Tahun 2010 tentang Pola Penerimaan Mahasiswa Baru Program Sarjana pada Perguruan Tinggi yang diselenggarakan oleh Pemerintah. Dalam Pasal 3 menyebutkan bahwa perguruan tinggi dalam penjaringan penerimaan mahasiswa baru wajib paling sedikit $60 \%$ mahasiswa baru pada setiap program studi melalui penerimaan mahasiswa baru secara nasional. Sisanya, maksimal $40 \%$ dapat dimanfaatkan oleh perguruan tinggi untuk penerimaan jalur mandiri. Jalur mandiri ini tidak diatur secara nasional, tetapi diserahkan pada masing-masing PTN nya. (Usman, 2015)

Salah satu tujuan Pendidikan Tinggi (PT) di Indonesia adalah 'menyiapkan peserta didik menjadi anggota masyarakat yang memiliki kemampuan akademik dan/atau professional yang dapat menerapkan, mengembangkan dan/atau menciptakan ilmu pengetahuan, teknologi dan/atau kesenian'. (PP RI Nomor 30 Tahun 1990) dalam (Wikarya, 2011).

Jalur masuk perguruan tinggi merupakan seleksi masuk PTN yang bertujuan untuk menjaring dan menyaring calon mahasiswa yang mempunyai kemampuan akademik untuk mengikuti dan menyelesaikan pendidikan di PTN sesuai dengan batas waktu yang ditetapkan (Depdikbud, 1994). Upaya penjaringan dan penyaringan dilakukan karena jumlah pelamar lebih besar dari kebutuhan PTN.

Seleksi dilakukan melalui beberapa jalur dengan jalan mengadakan pengukuran terhadap kemampuan dan potensi peserta seleksi. Mengingat pentingnya putusan seleksi, maka sistem seleksi sekurang-kurangnya harus mempertimbangkan azas: kecermatan prediksi (prediction effectiveness), efisiensi ekonomis (economic efficiency), dampak sistem seleksi terhadap belajar mengajar (teaching-learning incentive), dan keadilan (equity) (Asnawi, 1989; Sumadi Suryabrata, 1989). Persyaratan sistem seleksi berikutnya adalah keadilan, yaitu memberi kesempatan yang sama untuk mendaftar dan diterima di PTN (Mardapi \& Azwar, 1989) dalam (Wikarya, 2011)

Dalam UU No. 20 tahun 2003 tentang Sistem Pendidikan Nasional, pasal 3, disebutkan bahwa 'Pendidikan Nasional bertujuan mencerdaskan kehidupan bangsa dan mengembangkan manusia Indonesia seutuhnya yaitu manusia yang beriman dan bertaqwa terhadap Tuhan Yang Maha Esa dan berbudi pekerti luhur, memiliki pengetahuan dan keterampilan, kesehatan jasmani dan rohani, kepribadian yang mantap dan mandiri serta rasa tanggung jawab kemasyarakatan dan kebangsaan'. Dalam UU No. 12 tahun 2012 tentang udang-undang perguruan tinggi, pasal 6, bagian (g) juga disebutkan bahwa 'Kebebasan dalam memilih program studi berdasarkan minat, bakat, dan kemampuan mahasiswa'. 
Sesuai dengan undang-undang sisdiknas dan undang-undang perguruan tinggi diatas, maka perguruan tinggi sebagai lembaga pendidikan mempunyai peran untuk mewujudkan tujuan pendidikan nasional dan wajib menyelenggarakan proses seleksi masuk perguruan tinggi. (Utomo \& Tuasikal, 2015)

Di UNM sendiri pada tahun 2013 menetapkan sebesar 50\% dari 5.000 mahasiswa baru diterima melalui jalur SNMPTN. Pada tahun 2016 sebanyak 4.100 mahasiswa baru diterima melalui tiga jalur seleksi yakni SNMPTN sebanyak 1.299 mahasiswa baru atau sebesar $32 \%$, SBMPTN sebanyak 1.901 mahasiswa baru atau sebesar 46\%, dan Mandiri sebanyak 900 mahasiswa baru atau sebesar 22\%, Sedangkan pada tahun 2017 kuota mahasiswa baru mungkin bertambah hingga 6.000 mahasiswa baru yang diterima melalui tiga jalur selesksi, dimana untuk sekolah dengan akreditasi A mendapat undangan 50 persen siswa terbaiknya, akreditasi B 30 persen, akreditasi $\mathrm{C}$ hanya 10 persen dan akreditasi lainya 5 persen.

Berdasarkan data tersebut dapat diketahui bahwa kuota mahasiswa yang masuk di Universitas Negeri Makassar terus mengalami perubahan dari tahun ke tahun namun dapat terlihat bahwa sebagian besar mahasiswa baru diterima melalui jalur nasional yakni SNMPTN dan SBMPTN dimana diketahui pada tahun 2013 sebesar 50\% mahasiswa baru diterima melalui jalur SNMPTN dan pada tahun 2016 sebesar $46 \%$ diterima melalui jalur SBMPTN dan hanya $22 \%$ pada tahun 2016 diterima melalui jalur Mandiri. Berdasarkan perbedaan jalur masuk ini dapat diketahui bahwa sebagian besar PTN di Indonesia termasuk UNM masih didominasi oleh mahasiswa yang diterima melalui seleksi nasional.

Seleksi Nasional Masuk Perguruan Tinggi Negeri (SNMPTN), dilakukan berdasarkan proses seleksi penilaian melalui tiga indeks yaitu indeks siswa, indeks sekolah, dan indeks wilayah. Indeks siswa akan dinilai melalui indikator; nilai rapor, kelengkapan nilai rapor, dan pencapaian nilai pelajaran dibanding Kriteria Ketuntasan Minimal (KKM), nilai Ujian Nasional (UN), dan prestasi lainnya. Indeks Sekolah akan melalui indikator; Nilai rata-rata UN, Nilai SBMPTN alumninya, Akreditasi Sekolah, dan jumlah siswa yang diterima di PTN melalui jalur SBMPTN dan SNMPTN pada tahun sebelumnya. Untuk Indeks wilayah dimaksudkan untuk memperhatikan azas pemerataan (SNMPTN, 2017).

Selain SNMPTN jalur penerimaan mahasiswa baru secara nasional pemerintah juga menyelenggarakan Seleksi Bersama Masuk Perguruan Tinggi Negeri (SBMPTN). SBMPTN adalah pengganti jalur SNMPTN sebelumnya yang dilakukan berdasarkan proses seleksi dalam bentuk ujian tulis, ujian ini dilaksanakan secara serentak di seluruh Indonesia. Jalur ini diharapkan dapat menjadi alternatif bagi siswa yang tidak dapat mengikuti jalur SNMPTN. Selain itu SBMPTN memberikan kesempatan bagi lulusan tahun sebelumnya yang ingin mencoba kembali mendaftar di Perguruan Tinggi Negeri. Selanjutnya Perguruan Tinggi Negeri diperbolehkan juga menerima mahasiswa baru lewat ujian lokal yang biasa disebut jalur mandiri. Pelaksanaan Jalur mandiri diserahkan sepenuhnya ke setiap PTN, ketentuan, prosedur dan kriteria jalur mandiri berbeda di setiap PTN.

Setelah diterima sebagai mahasiswa di jurusan Fisika FMIPA UNM, semua mahasiswa diperlakukan sama, mengambil mata kuliah yang sama sesuai dengan kurikulum Program Studi yang diikutinya. Kondisi seperti ini menimbulkan pertanyaan, apakah dengan berbedanya jalur masuk yang ditempuh calon mahasiswa juga akan membedakan hasil belajar yang didapatkannya setelah mengikuti kegiatan pembelajara di jurusan Fisika FMIPA UNM?

Berdasarkan hal tersebut, peneliti bermaksud untuk melakukan penelitian untuk 
mendeskripsikan hasil belajar mata kuliah fisika dasar mahasiswa jurusan fisika FMIPA UNM dengan cara memberikan tes dan berdasarkan IPK mahasiswa tahun akademik 2017/2018 yang diterima melalui jalur SNMPTN, SBMPTN, dan Mandiri.

\section{METODE}

Jenis penelitian ini adalah penelitian Deskriptif. Penelitian ini dilakukan di jurusan Fisika FMIPA UNM pada semester ganjil tahun akademik 2017/2018. Subjek penelitian ini adalah seluruh mahasiswa jurusan fisika FMIPA UNM angkatan 2017 semester ganjil tahun akademik 2017/2018 sebanyak 129 mahasiswa. Penelitian dilaksanakan dengan memberikan tes sebanyak dua kali. Selain data tes, ada pula data dokumentasi IPK mahasiswa angkatan 2017 pada semester ganjil tahun akademik 2017/2018. Data yang diperoleh kemudian di analisis secara deskriptif.

\section{HASIL DAN PEMBAHASAN}

\section{A. Hasil}

1. Deskripsi Hasil Belajar Mahasiswa Pada Mata Kuliah Fisika Dasar

Hasil belajar merupakan hasil yang dicapai oleh mahasiswa dari adanya proses belajar yang dapat dinyatakan secara kulitatif maupun kuantitatif dan merupakan umpan balik dari kegiatan proses belajar mengajar yang dapat diukur dan diketahui dengan mengadakan penelitian dan evaluasi yang menunjukan sudah sejauh mana suatu kemampuan telah tercapai. Mengolah dan menganalisis secara deskriptif untuk mendapatkan gambaran tentang hasil belajar mahasiswa jurusan fisika berdasarkan jalur masuk ke perguruan tinggi angkatan 2017 semester genap tahun akademik 2017/2018 Universitas Negeri Makassar. Adapun gambaran statistik deskriptif hasil belajar mahasiswa adalah sebagai berikut:

Tabel 1. Statistik hasil belajar mahasiswa berdasrkan jalur masuk pada tes I dan tes II mata kuliah fisika dasar

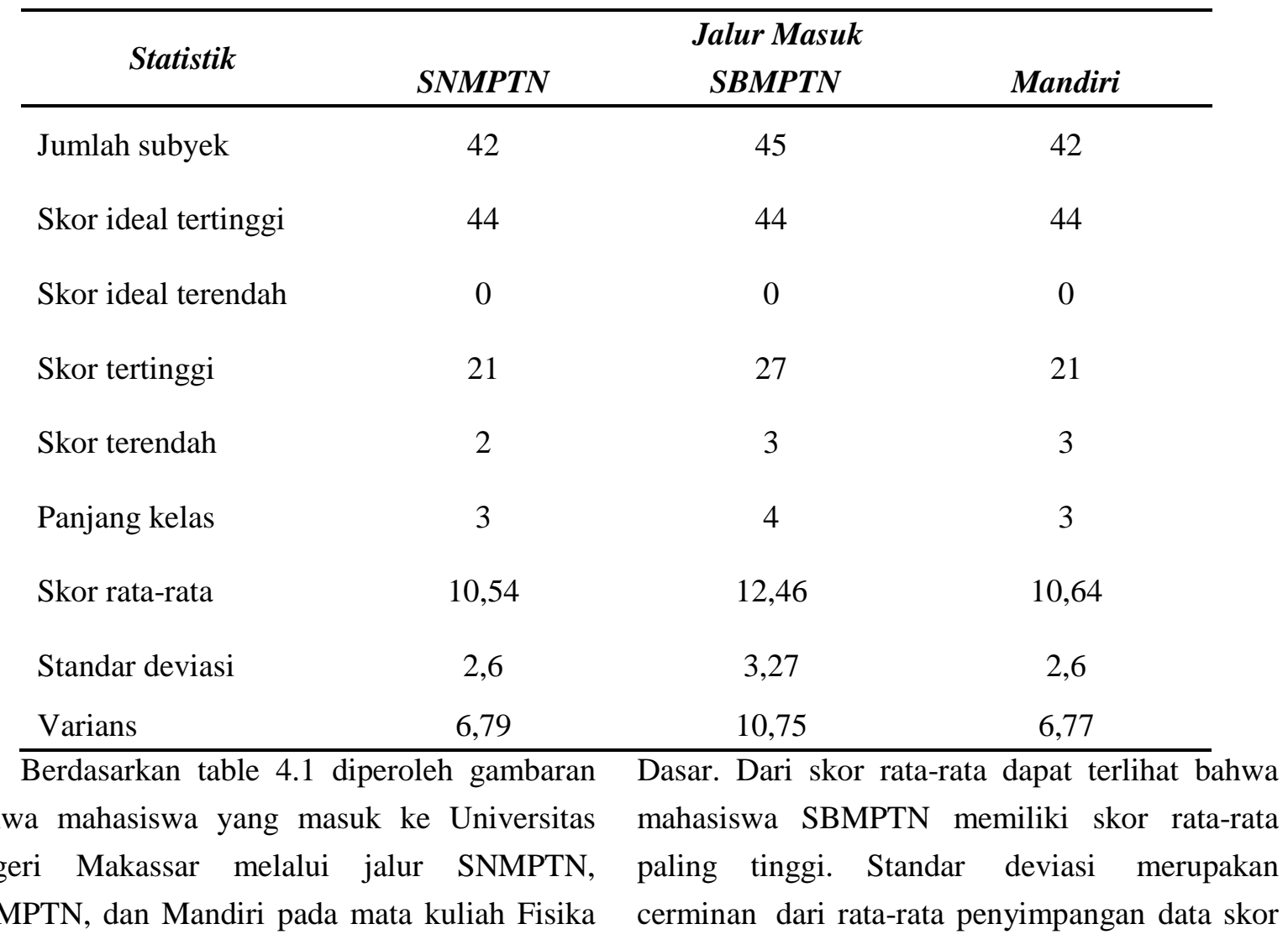


rata-rata. Standar deviasi dapat menggambarkan seberapa jauh bervariasinya data. Jumlah subyek keseluruhan adalah 129 orang:

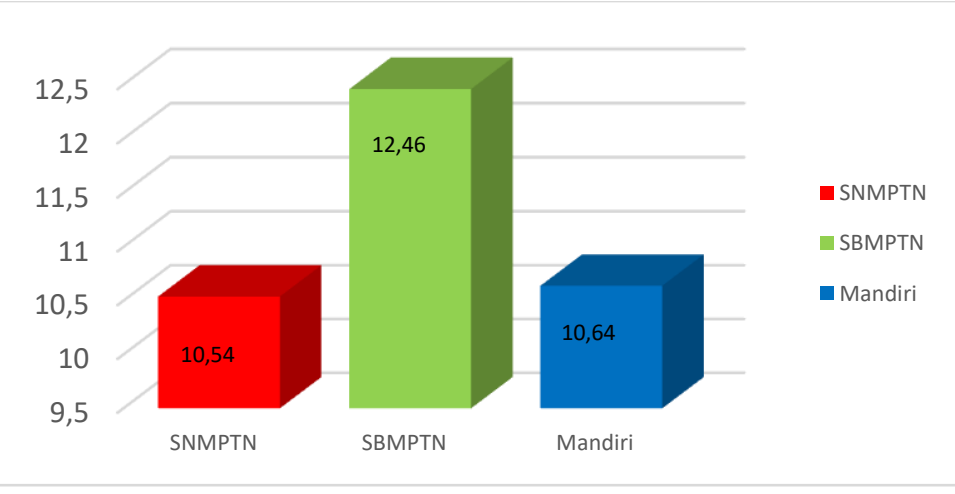

Gambar 1. Diagram Batang Hasil Belajar Mata Kuliah Fisika Dasar Mahasiswa Jurusan Fisika Pada Tes I dan Tes II

Gambar 4.1 Menunjukan gambaran jurusan fisika berdasarkan jalur masuk skor rata-rata yang diperoleh mahasiswa SNMPTN, SBMPTN dan Mandiri.

Tabel 2. Kriteria hasil belajar fisika dasar mahasiswa jurusan Fisika angkatan 2017 berdasarkan jalur masuk SNMPTN pada tes I dan tes II

\begin{tabular}{cccc}
\hline No. & $\begin{array}{c}\text { Interval Persentase Skor } \\
\text { Hasil Belajar }\end{array}$ & Jumlah Mahasiswa & Kriteria \\
\hline 1. & $80 \%-100 \%$ & 0 & Baik Sekali \\
2. & $66 \%-79 \%$ & 0 & Baik \\
3. & $56 \%-65 \%$ & 0 & Cukup \\
4. & $40 \%-55 \%$ & 6 & Kurang \\
5. & $30 \%-39 \%$ & 36 & Gagal \\
\hline
\end{tabular}

Tabel 2 menunjukan hasil belajar mahasiswa jurusan Fisika angkatan 2017 berdasarkan jalur masuk SNMPTN.

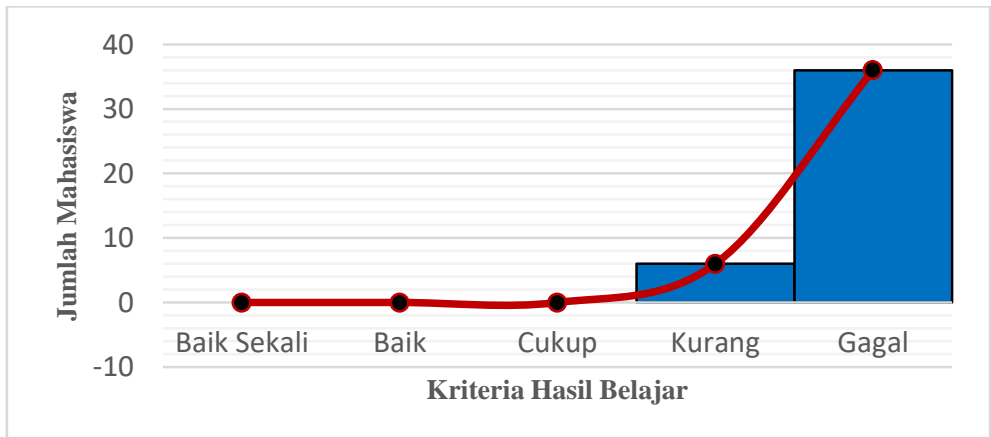

Gambar 2. Grafik Distribusi Hasil Belajar Dengan Jumlah Mahasiswa Berdasarkan Jalur Masuk SNMPTN

Tabel 3. Kriteria hasil belajar fisika dasar mahasiswa jurusan Fisika angkatan 2017 berdasarkan jalur masuk SBMPTN pada tes I dan tes II

\begin{tabular}{cccc}
\hline No. & $\begin{array}{c}\text { Interval Persentase Skor } \\
\text { Hasil Belajar }\end{array}$ & Jumlah Mahasiswa & Kriteria \\
\hline 1. & $80 \%-100 \%$ & 0 & Baik Sekali
\end{tabular}




\begin{tabular}{lccccc} 
& 2. & $66 \%-79 \%$ & 0 & Baik \\
& $\mathrm{G}$ & 3. & $56 \%-65 \%$ & 0 & Cukup \\
\multirow{2}{*}{$\begin{array}{l}\text { ambar } \\
3\end{array}$} & 4. & $40 \%-55 \%$ & 3 & Kurang \\
3 & 5. & $30 \%-39 \%$ & 39 & Gagal \\
\hline
\end{tabular}

menunjukan hasil belajar mahasiswa jurusan

Fisika angkatan 2017 berdasarkan jalur masuk

SBMPTN.

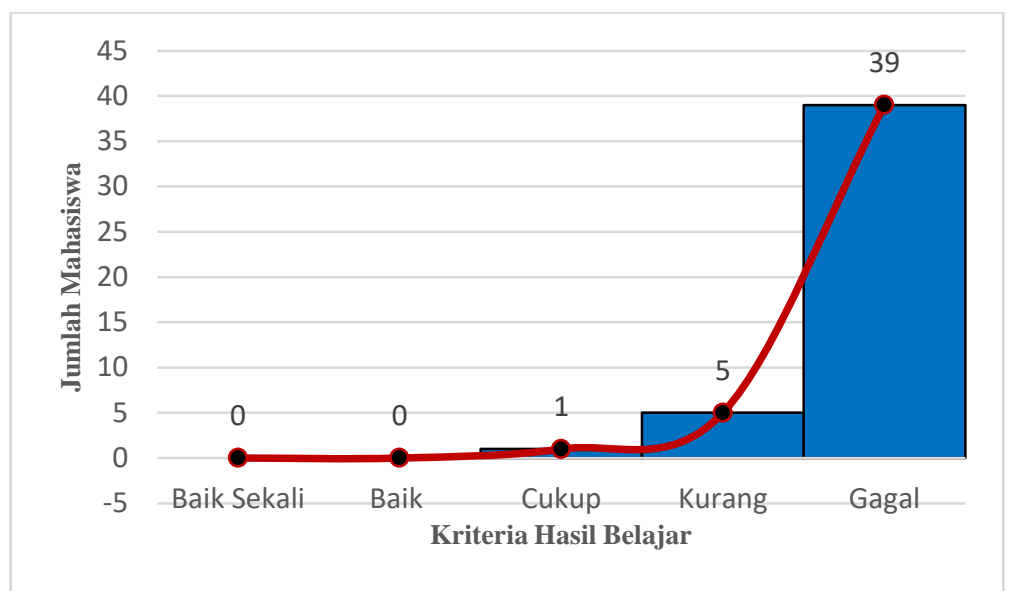

Gambar 3. Grafik Distribusi Hasil Belajar Dengan Jumlah Mahasiswa Berdasarkan Jalur Masuk SBMPTN

Tabel 4. Kriteria hasil belajar fisika dasar mahasiswa jurusan Fisika angkatan 2017 berdasarkan jalur masuk Mandiri pada tes I dan tes II

\begin{tabular}{cccc}
\hline & Interval Persentase Skor & & \\
No. & Jumlah Mahasiswa & Kriteria \\
& $80 \%-100 \%$ & 0 & \\
\hline 1. & $66 \%-79 \%$ & 0 & Baik Sekali \\
2. & $56 \%-65 \%$ & 1 & Baik \\
3. & & Cukup \\
\hline
\end{tabular}

Tabel 4 menunjukan hasil belajar mahasiswa jurusan Fisika angkatan 2017 berdasarkan jalur masuk Mandiri

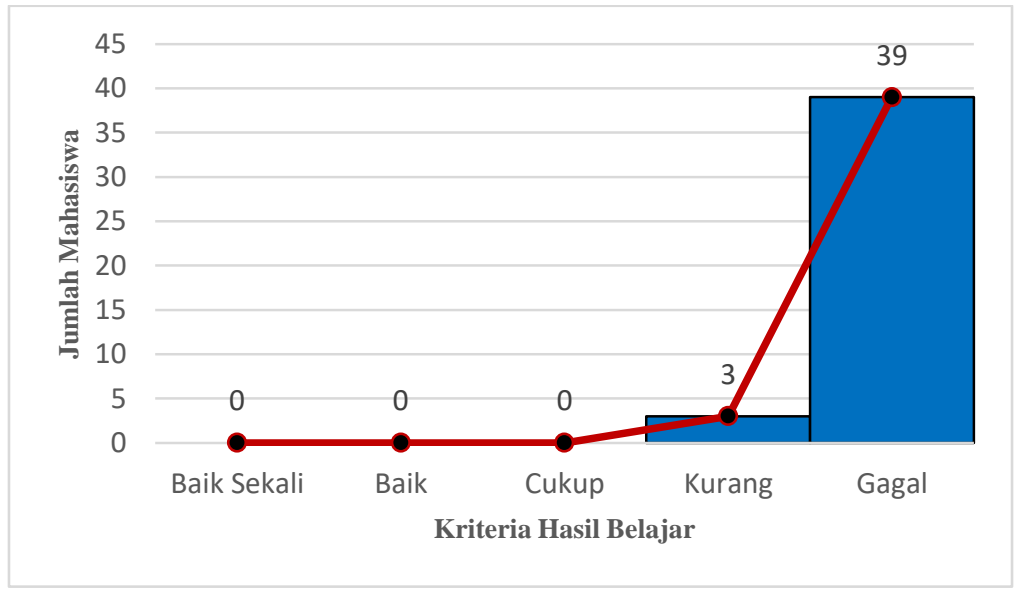


Gambar 4. Grafik Distribusi Hasil Belajar Dengan Jumlah Mahasiswa Berdasarkan Jalur Masuk Mandiri

2. Analisis Hasil Belajar Mahasiswa Jurusan Fisika Angkatan 2017 berdasarkan IPK (Indeks Prestasi Kumulatif) Berdasarkan Jalur Masuk SNMPTN, SBMPTN, dan Mandiri

Tabel 5. Hasil Belajar Mahasiswa berdasarkan IPK (Indeks Prestasi Kumulatif) Jurusan Fisika Angkatan 2017 berdasarkan jalur masuk SNMPTN

\begin{tabular}{ccccc}
\hline No. & $\begin{array}{c}\text { Interval IPK } \\
\text { Mahasiswa }\end{array}$ & Kriteria & $\mathrm{f}$ & $\%$ \\
\hline 1 & $0-2.75$ & Tidak memenuhi syarat IPK & 5 & $11.90 \%$ \\
2 & $2.76-3.00$ & Memuaskan & 7 & $16.67 \%$ \\
3 & $3.01-3.50$ & Sangat Memuaskan & 29 & $69.05 \%$ \\
4 & $3.51-4.00$ & Cumlaude & 1 & $2.38 \%$ \\
\hline
\end{tabular}

Tabel 5 menunjukan hasil belajar Prestasi Kumulatif) berdasarkan jalur masuk mahasiswa jurusan Fisika angkatan 2017 tahun SNMPTN.

akademik 2017/2018 berdasarkan IPK (Indeks

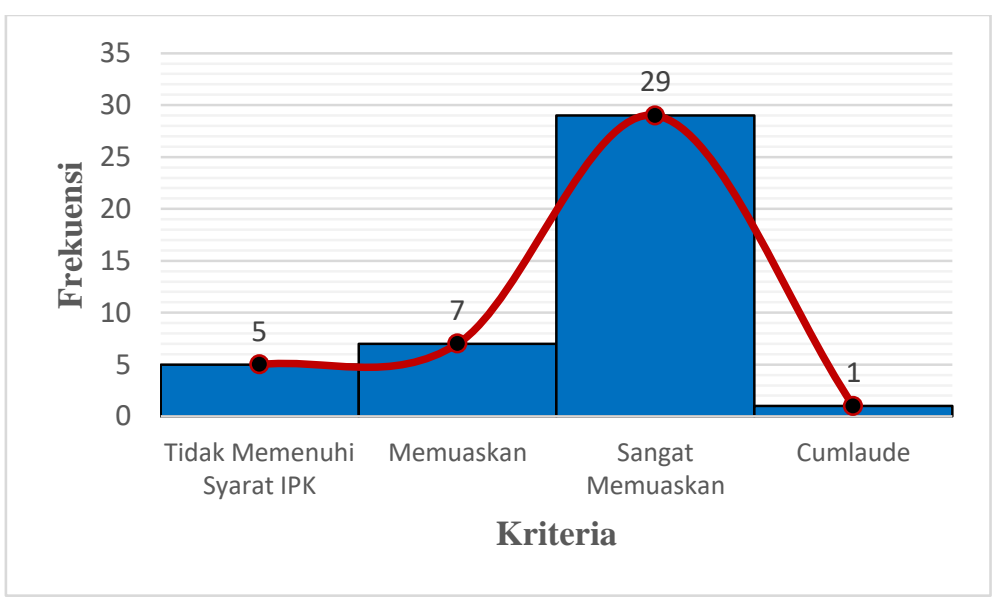

Gambar 5. Grafik Distribusi Hasil Belajar Dengan Jumlah Mahasiswa Berdasarkan Jalur Masuk SNMPTN Berdasarkan IPK

Tabel 5. Hasil Belajar Mahasiswa berdasarkan IPK (Indeks Prestasi Kumulatif) Jurusan Fisika Angkatan 2017 berdasarkan jalur masuk SBMPTN

\begin{tabular}{ccccc}
\hline No. & $\begin{array}{c}\text { Interval IPK } \\
\text { Mahasiswa }\end{array}$ & Kriteria & $\mathrm{f}$ & $\%$ \\
\hline 1 & $0-2.75$ & Tidak memenuhi syarat IPK & 5 & $11,11 \%$ \\
2 & $2.76-3.00$ & Memuaskan & 6 & $13,33 \%$ \\
3 & $3.01-3.50$ & Sangat Memuaskan & 26 & $57,78 \%$ \\
4 & $3.51-4.00$ & Cumlaude & 8 & $17,78 \%$ \\
\hline
\end{tabular}

Tabel 5 menunjukan hasil belajar $\quad$ Prestasi Kumulatif) berdasarkan jalur masuk mahasiswa jurusan Fisika angkatan 2017 tahun SBMPTN.

akademik 2017/2018 berdasarkan IPK (Indeks 


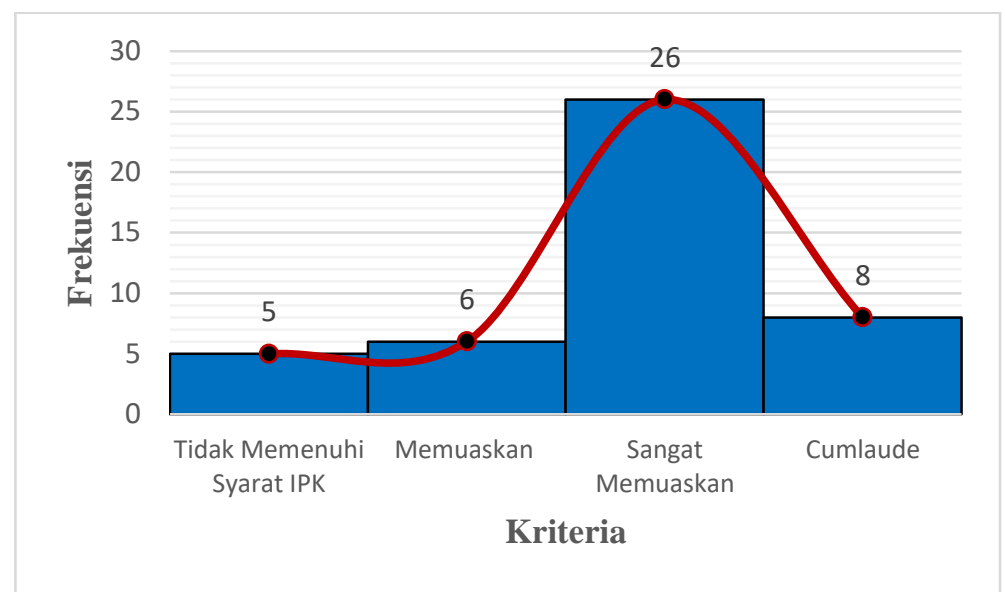

Gambar 6. Grafik Distribusi Hasil Belajar Dengan Jumlah Mahasiswa Berdasarkan Jalur Masuk SBMPTN Berdasarkan IPK

Tabel 6. Hasil Belajar Mahasiswa berdasarkan IPK (Indeks Prestasi Kumulatif) Jurusan Fisika Angkatan 2017 berdasarkan jalur masuk Mandiri

\begin{tabular}{ccccc}
\hline No. & $\begin{array}{r}\text { Interval IPK } \\
\text { Mahasiswa }\end{array}$ & Kriteria & $\mathrm{f}$ & $\%$ \\
\hline 1 & $0-2.75$ & Tidak memenuhi syarat & 10 & $23,81 \%$ \\
2 & $2.76-3.00$ & IPK & 9 & $21,43 \%$ \\
3 & $3.01-3.50$ & Memuaskan & 22 & $52,38 \%$ \\
4 & $3.51-4.00$ & Sangat Memuaskan & 1 & $2,38 \%$ \\
\hline
\end{tabular}

Prestas

Tabel 6 menunjukan hasil belajar mahasiswa jurusan Fisika angkatan 2017 tahun

i Kumulatif) berdasarkan jalur masuk Mandiri akademik 2017/2018 berdasarkan IPK (Indeks

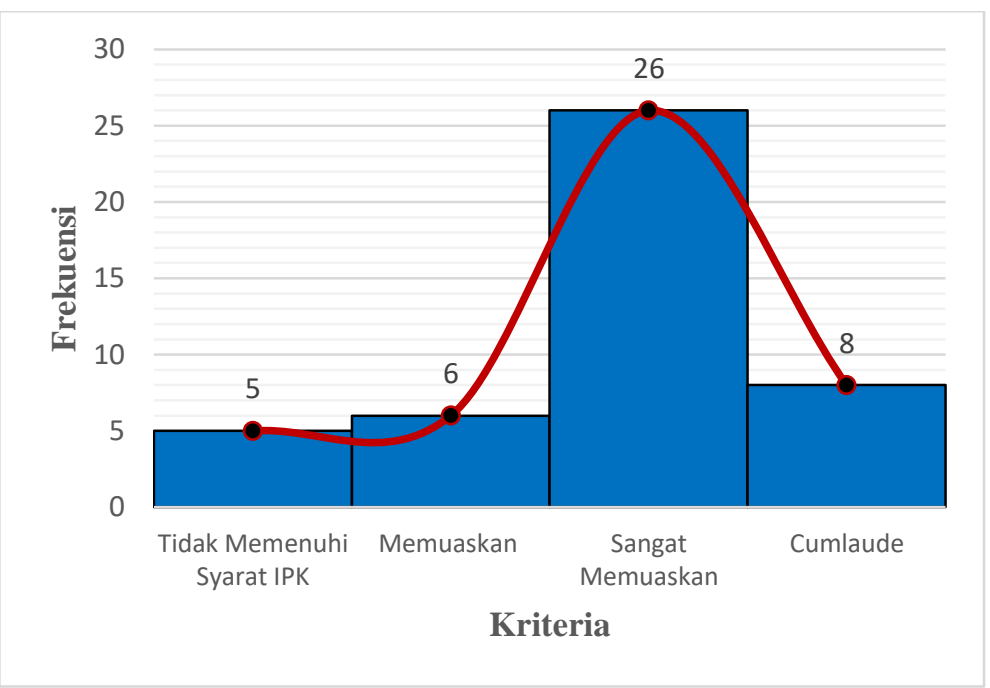

Gambar 7. Grafik Distribusi Hasil Belajar Dengan Jumlah Mahasiswa Berdasarkan Jalur Masuk Mandiri Berdasarkan IPK 


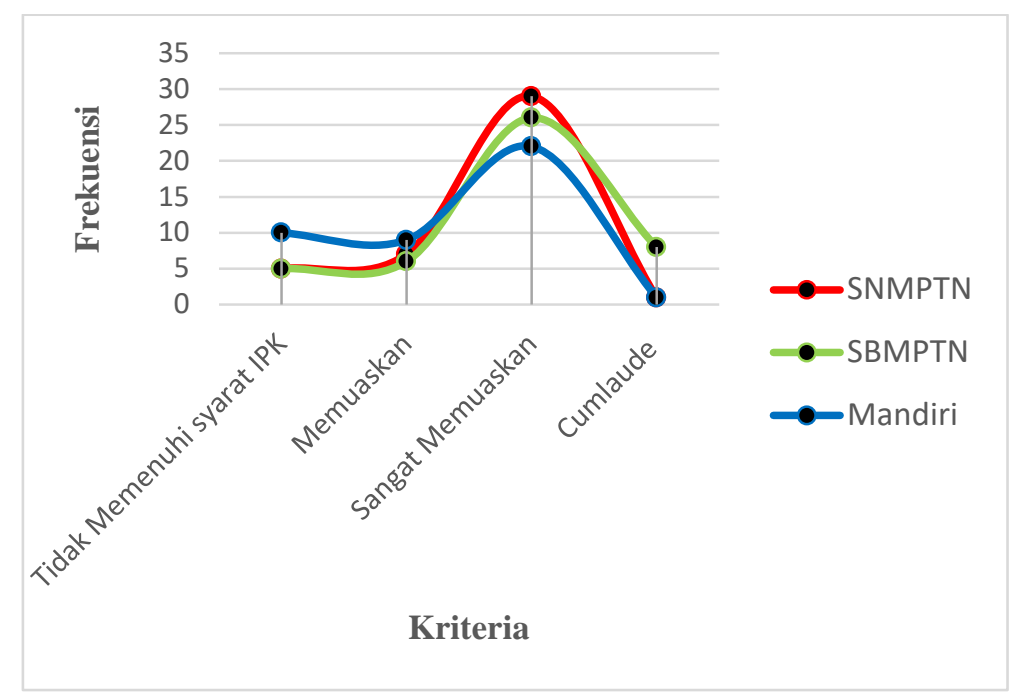

Gambar 8. Diagram Garis Hasil Belajar Mahasiswa Jurusan Fisika Berdasarkan IPK Berdasarkan Jalur Masuk SNMPTN, SBMPTN, dan Mandiri

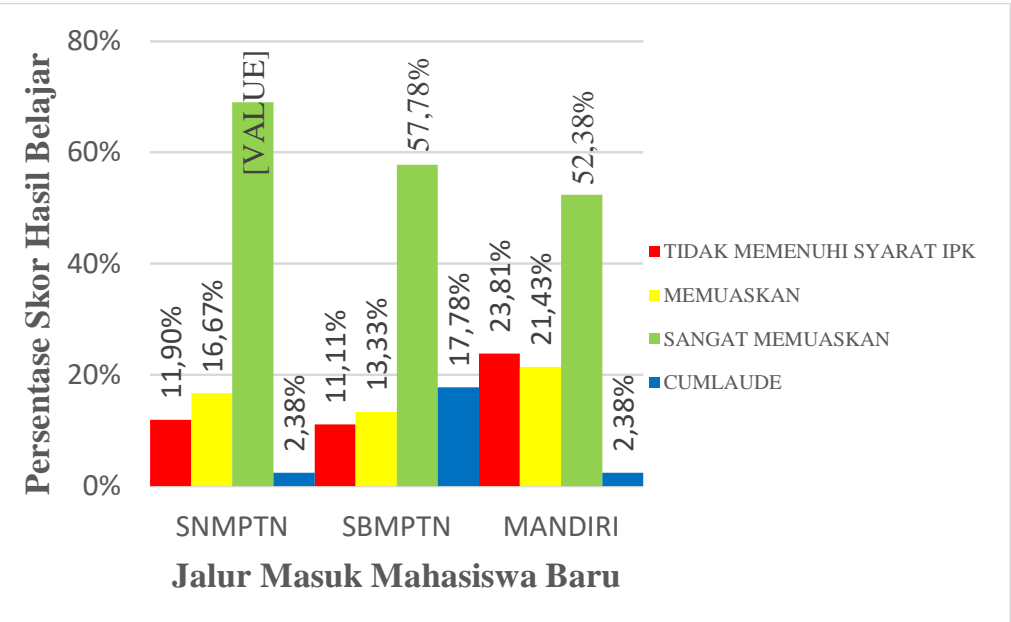

Gambar 9. Histogram hasil belajar mahasiswa berdasarkan IPK jurusan fisika berdasarkan jalur masuk SNMPTN, SBMPTN, dan Mandiri

Gambar 8 menunjukan gambaran hasil (Indeks Prestasi Kumulatif) berdasarkan jalur belajar mahasiswa jurusan Fisika angkatan 2017 masuk SNMPTN, SBMPTN, dan Mandiri di tahun akademik 2017/2018 berdasarkan IPK Universitas Negeri Makassar.

B. Pembahasan

Pada sub bab ini akan disajikan pembahasan mengenai hasil penelitian yang telah dilakukan, penelitian ini merupakan penelitian deskriptif kuantitatif. Penelitian ini bertujuan untuk mengetahui deskripsi hasil belajar mahasiswa jurusan Fisika berdasarkan jalur masuk SNMPTN, SBMPTN, dan Mandiri.

Hasil belajar pada penelitian ini disajikan dalam bentuk skor rata-rata yang diperoleh melalui tes sebanyak 2(dua) kali selama semester ganjil tahun akademik
2017/2018 mahasiswa jurusan Fisika berdasarkan jalur masuk PTN, dan untuk mengetahui gambaran perbedaan dapat dilihat dari analisis deskriptif dari setiap jalur masuk.

Berdasarkan perhitungan statistik deskriptif, perbedaan hasil belajar mahasiswa Jurusan Fisika angkatan 2017 berdasarkan jalur masuk SNMPTN, SBMPTN, dan Mandiri terlihat jelas dalam hasil penelitian. Rata-rata skor hasil belajar mahasiwa berdasarkan hasil tes sebanyak 2 kali pada mata kuliah Fisika Dasar pada semester ganjil tahun akademik 
2017/2018 mahasiswa yang diterima melalui jalur SNMPTN memiliki skor rata-rata 10,54, SBMPTN 12,46, dan Mandiri 10,64.

Berdasarkan IPK(Indeks Prestasi Kumulatif) mahasiswa jurusan Fisika angkatan 2017 tahun akademik 2017/2018 jumlah mahasiswa yang memiliki predikat cumlaude paling banyak adalah mahasiswa SBMPTN yakni sebanyak 8 orang atau $17,78 \%$, dan yang tidak memenuhi syarat IPK sebanyak 5 orang atau $11,11 \%$, diikuti mahasiswa SNMPTN yakni sebanyak 1 orang memiliki predikat cumlaude atau sebesar $2,38 \%$, dan yang tidak memenuhi syarat IPK sebanyak 5 orang atau sebesar 11,90\%, terakhir mahasiswa Mandiri yakni sebanyak 1 orang memiliki predikat cumlaude atau sebesar $2,38 \%$, dan yang tidak memenuhi syarat IPK sebanyak 10 orang atau sebesar $23,81 \%$.

Berdasarkan hasil dalam penelitian ini dapat diketahui bahwa mahasiswa yang diterima melalui jalur SBMPTN memiliki hasil belajar yang paling tinggi, hal tersebut sebenarnya tidak sejalan dengan dengan tujuan seleksi mahasiswa baru. dengan melihat proses seleksi mahasiswa baru dimana mahasiswa yang diterima melalui jalur SNMPTN adalah siswa yang berprestasi di SMA/SMK maupun MA, yang diterima tanpa tes, dan kuota mahasiswa yang diterima melalui jalur SNMPTN adalah yang paling besar dibandingkan jalur SBMPTN, dan Mandiri. Meskipun demikian, hasil dalam penelitian ini menunjukan bahwa mahasiswa yang diterima melalui jalur SBMPTN memiliki hasil belajar tertinggi karna adanya factor-faktor lain yang dapat mempengaruhi hasil belajar mahasiswa seperti perbedaan lingkungan, perbedaan proses pembelajaran, serta perbedaan sistem penilaian.

Hasil penelitian ini tidak sejalan dengan tujuan dari seleksi SNMPTN. Mahasiswa yang diterima melalui jalur ini sangat di istimewakan karna diterima tanpa tes. Berbeda dengan mahasiswa jalur SBMPTN, sebelum diterima terlebih dahulu melakukan tes yang diantaranya Tes Potensi Akademik (TPA) dan Tes Bidang Studi Dasar (TBDS). Sedangkan mahasiswa yang diterima melalui jalur Mandiri hampir sama dengan mahasiswa yang diterima melalui jalur SBMPTN, hanya saja biaya kuliah per semesternya lebih tinggi.

\section{SIMPULAN}

Berdasarkan penelitian dan analisis data yang dilakukan maka dapat disimpulkan bahwa mahasiswa yang memiliki skor rata-rata hasil belajar tertinggi adalah mahasiswa yang diterima melalui jalur SBMPTN, demikian pula mahasiswa yang memiliki predikat hasil belajar terbaik (cumlaude) adalah mahasiswa SBMPTN yakni sebesar 17,78\% sedangkan SNMPTN dan Mandiri sama yaitu 2,38\%.

\section{DAFTAR RUJUKAN}

Buku Panduan Mahasiswa Baru . (2013). In Selamat Datang Mahasiswa Baru Universitas Negeri Makassar. Makassar: Badan Penerbit UNM.

Darmadi, H. (2011). Metode Penelitian Pendidikan. Pontianak: Alfabeta Bandung.

Dr. Purwanto, M. (2014). Evaluasi Hasil Belajar. Yogyakarta: Pustaka Pelajar.

Gulo, W. (2000). Metodologi Penelitian. Jakarta: Grasindo.

Informasi Umum SNMPTN 2017. (2017, maret 22). Retrieved from SNMPTN: www.snmptn.co.id

Kementrian Pendidikan Nasional; 2010. Peraturan Menteri Pendidikan Nasional Nomor 34 Tahun 2010. Jakata; Kementerian Pendidikan Nasional. 
Nana Sudjana. 1991. Penilaian Hasil Proses Belajar Mengajar. Bandung: Remaja Rosdakarya.

Nasution, S., 2006. Berbagai Pendekatan dalam Proses Belajar dan Mengajar, Jakarta: Bumi Aksara.

Panduan Universitas Negeri Makassar. (2013/2014). Makassar: Badan Penerbit UNM.

Penerimaan Mahasiswa baru 2017. (2017, Januari 24). UNM Sediakan Kuota Mahasiswa Baru Hingga 6000 Orang, p. TRIBUNnews.com.

Purwanto. (2014). Evaluasi Hasil Belajar. Yogyakarta: Pustaka Pelajar.

Riduwan . (2003). Skala Pengukuran Variabelvariabel Penelitian. Bandung: Alfabeta.

Saputra, E. K. (2016). Studi Komparatif Prestasi Belajar Mahasiswa Jurusan Pendidikan Ekonomi Ditinjau Dari alur Penerimaan Mahasiswa Baru Tahun 2011. Jurnal Jurusan Pendidikan Ekonomi (JJPE) Volume: 6 Nomor: 1.

SBMPTN. (2017, maret 22). Retrieved from Informasi Umum SBMPTN 2017: www.sbmptn.co.id

SNMPTN. (2017, maret 22). Retrieved from Informasi Umum SNMPTN 2017: www.snmptn.co.id

Subino (1987), Konstruksi dan Analisis Tes Jakarta: Ditjen Dikti

Sudarisman, S. (2015). Memahami Hakikat Dan Karakteristik Pembelajaran Biologi Dalam Upaya Menjawab Tantangan Abad 21 Serta Optimalisasi Implementasi Kurikulum 2013. Jurnal Florea Volume 2 No.1 , 29-35.

Sugiyono. (2012). Metode Penelitian Pendekatan Kuantitatif Kualitatif Dan R\&D. Bandung: Alfa Beta
Tabrani, A. R., Atang, K., \& Arifin. (1989). Pendekatan Dalam Proses Belajar Mengajar. Bandung: Rineka Cipta.

Usman. (2015). Analisis Perbandingan Prestasi Belajar Fisika Dasar Mahasiswa Berdasarkan Jalur Penerimaan Mahasiswa Di Jurusan Fisika Fakultas Matematika dan Ilmu Pengetahuan Alam Universitas Negeri Makassar. Jurnal Sains dan Pendidikan Fisika $(J S P F)$, jilid 11 Nomor 1.

Utomo, F. L., \& Tuasikal, A. R. (2015). Perbandingan Motivasi Belajar, Prestasi Belajar Akademik dan Non Akademik Antara Mahasiswa Jalur SNMPTN Undangan Dengan Jalur SPMB (Studi Pada Mahasiswa Prodi S-1 Penjaskesrek Angkatan 2013 FIK UNESA). jurnal pendidikan olahraga dan kesehatan volume 03 nomor 02, 361-366.

Wijaya, E. Y., Sudjimat, D. A., \& Nyoto, A. (2016). Tranformasi Pendidikan Abad 21 Sebagai Tuntutan Pengembangan Sumber Daya Manusia Di Era Global. ISSN 2528-259X Volume 1.

Wikarya, Y. (2011). Komparasi Hasil Belajar Mahasiswa FBS UNP Padang Berdasarkan Jalur Masuk Perguruan Tinggi. Jurnal Bahasa dan Seni Vol 12 No. 2, 200-213.

Winkel, WS (1999), Psikologi Pengajaran Jakarta: PT Grasindo 